\title{
PRIMARY STRESS RESPONSES OF COMMON CARP, CYPRINUS CARPIO, EXPOSED TO COPPER TOXICITY
}

\author{
Mathan RAMESH ${ }^{1 *}$, Sathyanarayanan SENTHIL KUMARAN ${ }^{1}$, Chokkalingam KAVITH $^{1}$, \\ Manoharan SARAVANAN ${ }^{1}$, and Ahmed MUSTAFA ${ }^{2}$ \\ ${ }^{1}$ Unit of Toxicology, Department of Zoology, Bharathiar University, Coimbatore, India \\ ${ }^{2}$ Department of Biology, Indiana University Purdue University Fort Wayne, IN 46805, USA
}

\begin{abstract}
Ramesh M., Senthil Kumaran S., Kavith C., Saravanan M., Mustafa A. 2007. Primary stress responses of common carp, Cyprinus carpio, exposed to copper toxicity. Acta Ichthyol. Piscat. 37 (2): 81-85.
\end{abstract}

\begin{abstract}
Background. Copper is a heavy metal, and an aquatic pollutant, known for its bio-accumulative and non-biodegradable properties. In the aquatic ecosystems, acute and sublethal concentrations of copper may be linked to a variety of effects. Recently, hormones, particularly those regulating vital functions, such as osmoregulation, energy metabolism, and reproduction, may be used as potential biomarkers for sublethal toxicity studies. In the present study, the potential effect of a heavy metal - copper on hormonal changes (cortisol and prolactin) in an economically important fresh-water fish-common carp, Cyprinus carpio, was examined.

Materials and Methods. The experimental fish were subjected to two experimental regimes (backed by controls). In the first treatment they were exposed to the acute concentration of copper sulphate, amounting to $0.7 \mathrm{ppm}$. The second treatment featured copper sulphate concentration of $0.07 \mathrm{ppm}$, constituting $10 \%$ of $\mathrm{LC}_{50}(24 \mathrm{~h})$. The acute-toxicity trials were carried out in two, 20-L, circular plastic tubs. Twenty fish from the tank were selected randomly and introduced to each tub. Control was maintained in 2 similar plastic tubs with 20 fish per tub. After $24 \mathrm{~h}$, fish from control- and copper-exposure tubs were taken for analyses. To observe the sublethal toxicity four, 125-L, glass aquaria, filled with clean water were used. 200 fish were randomly selected from the stock and 100 of them were added to two aquaria, 50 fish in each, as experimental fish and 100 in two other aquaria, 50 in each, for as control fish. By the end of the stipulated period, 20 fish from control and 20 fish from experimental group were used for the hormone assay.

Results. In both acute- and sublethal treatments, both cortisol- and prolactin levels increased. In sublethal treatment, however, plasma prolactin level decreased after 28-day exposure, showing a minimum percentage point decrease of 3.84 by the end of 35-day trial.

Conclusion. The increase of the plasma cortisol was probably caused by release of cortisol from the interrenal tissue, as a mechanism of coping with stress. Significantly lower content of prolactin levels in sublethal treatment could be an indicative of a possible restored hydromineral balance or atrophy of the pituitary prolactin cells leading to inhibited prolactin secretion of the fish. These alterations of the above hormonal changes may be used as stress biomarkers in fish.
\end{abstract}

Keywords: copper, acute, sublethal, cortisol, prolactin, fish, carp, Cyprinus carpio

\section{INTRODUCTION}

A wide range of chemicals has been shown to cause endocrine disturbances in living organisms. Under an environmental stress, organisms are known to exhibit primary response by way of changes in hormone levels, which in turn are known to stimulate the secondary responses including physiological and biochemical changes. The homeostasis of an animal is disturbed as a result of the actions of intrinsic and/or extrinsic stimuli or stressors (Wendelaar Bonga 1997). Among stressors, heavy metals are of greater importance because of their long biological half-lives, which pose a real threat to aquatic organisms, especially fish. In sub-acute concentrations, heavy metals gradually accumulate in various organisms, as they reach higher trophic levels of the food chain but at high concentrations heavy metal are lethal to aquatic organisms. Among the heavy metals, copper has been regarded as strongly toxic to fish and other aquatic animals (Sloman 2003). Copper, at high concentrations, causes disturbances in sodium- and chloride homeostasis and alters nitrogenous metabolites in aquatic animals (Bury et al. 2003, Sloman 2004). However, little is known about the effects of copper on stress modulation.

\footnotetext{
* Correspondence: Dr Mathan Ramesh, Unit of Toxicology, Department of Zoology, Bharathiar University, Coimbatore - 641046, India, fax: +91-422-2422387, e-mail: mathanramesh@yahoo.com
} 
Animal responses to stressors have been focused on the activation of the neuro-endocrine systems via, the hypothalamic-pituitary-inerrenal axis (HPI) (Donaldson 1981, Barton and Iwama 1991). Along this axis corticotropin release factors (CRF) are given off from the hypothalamus during stress stimulating the secretion of the pituitary hormones as prolactin (PRL) and adrenocorticotropin (ACTH) (Fu et al. 1990, Barton and Iwama 1991, Iwama et al. 2003). In turn, ACTH stimulates the synthesis and release of cortisol, the major corticosteroid from the interrenal cells in fish (Yang and Albright 1995). The role of cortisol as an intermediary in metabolism is vital, since it is the major gulcocorticosteroid secreted by the teleosts' interrenal tissue in response to adrenocorticotropic hormone stimulation (Yang and Albright 1995, Pottinger et al. 2000). Indeed, increased PRL release has been implicated in the successful adaptation of fish to acidic water (Wendelaar Bonga et al. 1984, 1987) and heavy metals (Fu et al. 1990). Thus, endocrine responses through their integrative- and early warning capacity may offer as potential indicators that may be useful in the detection and assessment of sublethal toxic stress in fish exposed to polluted environments. Hormones have been included in this study as they are easily measurable from the blood and have been validated for endocrine response. The objective of the presently reported study was to find out the primary responses (plasma cortisol and prolactin) in a freshwater teleost fish, Cyprinus carpio, exposed to acute- and sublethal copper toxicity.

\section{MATERIALS AND METHODS}

Fingerlings of scale carp, Cyprinus carpio carpio L., $(5-7 \mathrm{~cm})$ were procured from Tamil Nadu Fisheries Development Corporation Ltd., (Fish Farm, Alizhiar, Tamil Nadu, India) and were acclimated to laboratory conditions ( $24 \pm$ $2.0^{\circ} \mathrm{C}$ ) for 20 days. Fish were fed ad libitum with rice bran and ground nut oil cake ( $3: 1$ ratio) in the form of small dough, twice a day. A major portion of water was changed daily in order to avoid any accumulation of excretory products and unused feed, which might cause further stress to the fish. Since, physico-chemical features of water have significant influence on the biodegradability and toxicity of pollutants, hydrobiological parameters such as temperature $\left(26.0 \pm 2.0^{\circ} \mathrm{C}\right), \mathrm{pH}(7.1 \pm 0.1)$, salinity $(0.6 \pm 0.02$ $\mathrm{ppt})$, total hardness $\left(18.0 \pm 0.4 \mathrm{mg} \cdot \mathrm{L}^{-1}\right)$, calcium $(4.10 \pm$ $\left.0.5 \mathrm{mg} \cdot \mathrm{L}^{-1}\right)$, and magnesium $\left(2.2 \pm 0.6 \mathrm{mg} \cdot \mathrm{L}^{-1}\right)$ were measured by following the guidelines of Anonymous (1998) and were maintained throughout the study period.

Five hundred fish were stocked in a large cement tank $(122 \times 183 \times 91 \mathrm{~cm})$ after it was cleaned and disinfected with potassium permanganate. Fish with an average weight of $6.22 \mathrm{~g}$ and an average (total) length of $7.5 \mathrm{~cm}$ were selected for the experiment. The $\mathrm{LC}_{50}$ value of the copper sulphate for the fish $(=0.7 \mathrm{ppm})$ was calculated following the method of Finney (1978). The acute toxicity experiment was carried out in two circular plastic tubs, filled with 25 L of water. A normal pH (7.1) and copper sulphate concentration of $0.7 \mathrm{ppm}\left(\mathrm{LC}_{50} 24 \mathrm{~h}\right)$ were maintained throughout the experiment. Twenty fish, which were already with- held from feeding for $48 \mathrm{~h}$, were introduced into each tub. Control was maintained in 2 circular plastic tubs with 20 fish per tub. After 24 h, 40 randomly sampled fish, 20 each from the control- and treatment groups were used for the hormone assay.

Chronic effects of sublethal concentration of the toxicant were studied in four, 125-L glass aquaria, filled with clean water. The aquaria labelled A1 and A2 represented control and experimental, respectively. Aquarium A1 was filled with sublethal aqueous solution of copper sulphate of $0.07 \mathrm{ppm}\left(\mathrm{LC}_{50}=0.7 \mathrm{ppm}\right.$, as suggested by Sprague 1971) and Aquarium A2 was filled with clean water. Then 200 fish were randomly selected from the stock and added to these aquaria, 100 in each group, 50 in each replicate. Care was taken to minimize disturbances to the animals. After the stipulated time period ( $24 \mathrm{~h}$ for the acute study and 7 days for sublethal study) fish from control- and experimental aquaria were sacrificed and blood was collected by cardiac puncture using heparinised syringes and kept at low temperature $\left(4^{\circ} \mathrm{C}\right)$. A minimum of 10 fish, randomly selected from each replicate, 20 from each group, were used for further assays. All analyses were performed on pooled blood samples from fish of identical exposure times. Then the pooled blood samples were centrifuged for $15 \mathrm{~min}$ at 10 $000 \mathrm{rpm}$, the plasma was withdrawn, and transferred into clean vials for hormone analyses.

Plasma cortisol was estimated quantitatively by direct solid phase enzyme immunoassay according to the method of Tietz (1986) using EIA gen cortisol kit manufactured and supplied by IFCI Clone Systems, Casalecchio Di Reno, Italy by an automated microplate reader (Bio-Tek Instruments, USA) and plasma prolactin was estimated quantitatively by enzyme immunoassay by following the method of Engvall (1980) using Medix Biotech prolactin enzyme immunoassay test kit manufactured by Medix Biotech, Foster City, California and marketed by Span Diagnostics, India by an automated microplate reader. The method followed for the plasma prolactin is a heterologous assay and cross reactivity of the antiserum to native carp growth hormone and somatolactin is not known. This can be referred to as 'immunoreactive prolactin' (ir-PRL). Statistical correlation between control and experimental values were made by Student's $t$-test.

\section{RESULTS}

In the acute-toxicity study, plasma cortisol and prolactin levels of the experimental fish were elevated to $19.500 \pm$ $0.537 \mathrm{ng} \cdot \mathrm{mL}^{-1}$ and $5.00 \pm 0.126 \mathrm{ng} \cdot \mathrm{mL}^{-1}$ respectively compared to those of control fish $\left(6.110 \pm 0.105 \mathrm{ng} \cdot \mathrm{mL}^{-1}\right.$; $4.125 \pm 0.156 \mathrm{ng} \cdot \mathrm{mL}^{-1}$ ) showing a percentage-point increase of 219.14 and 21.21, respectively (Table 1). Statistical analyses of data, by Student's $t$-test, indicated that values were significant $(P<0.05)$. In the sublethal-toxicity treatment, plasma cortisol levels steadily increased up to day 14 , giving $96.24 \%$ increase $(9.800 \pm 0.505$ to 11.500 $\pm 0.411 \mathrm{ng} \cdot \mathrm{mL}^{-1}$ ) (Table 2). By the end of days 21,28 , and 35 , plasma cortisol level showed a recovery by a percentage-point increase of $38.27,38.03$, and 36.21 , assum- 
Table 1

Cortisol and prolactin levels in the plasma of Cyprinus carpio var. communis exposed to acute copper toxicity (values are means \pm standard error of five individual observations)

\begin{tabular}{lccc}
\hline Parameter & Control & Experiment & $\begin{array}{c}\text { Percentage-point } \\
\text { change }\end{array}$ \\
\hline Cortisol $\left[\mathrm{ng} \cdot \mathrm{mL}^{-1}\right]$ & $6.110 \pm 0.105$ & $19.500 \pm 0.537^{*}$ & +219.14 \\
Prolactin $\left[\mathrm{ng} \cdot \mathrm{mL}^{-1}\right]$ & $4.125 \pm 0.156$ & $5.00 \pm 0.126^{*}$ & +21.21 \\
\hline
\end{tabular}

* Significant difference $(P<0.05)$.

+ increase over control.

Table 2

Changes in the plasma cortisol and prolactin levels of Cyprinus carpio carpio exposed to varying periods of sublethal copper sulphate toxicity (Values are means \pm standard error of five individual observations)

\begin{tabular}{|c|c|c|c|c|}
\hline \multirow{2}{*}{$\begin{array}{l}\text { Exposure } \\
\text { time } \\
\text { [days] }\end{array}$} & \multicolumn{2}{|c|}{ Plasma cortisol level $\left[\mathrm{ng} \cdot \mathrm{mL}^{-1}\right]$} & \multicolumn{2}{|c|}{ Plasma prolactin level $\left[\mathrm{ng} \cdot \mathrm{mL}^{-1}\right]$} \\
\hline & control & experiment & control & experiment \\
\hline 7 & $6.00 \pm 0.254$ & $\begin{array}{c}9.800 \pm 0.505^{*} \\
(+63.33)\end{array}$ & $4.00 \pm 0.228$ & $\begin{array}{c}4.500 \pm 0.221 \\
(+12.50)\end{array}$ \\
\hline 14 & $5.860 \pm 0.152$ & $\begin{array}{c}11.500 \pm 0.411 * \\
(+96.24)\end{array}$ & $5.524 \pm 0.255$ & $\begin{array}{c}10.500 \pm 0.221 * \\
(+90.07)\end{array}$ \\
\hline 21 & $5.930 \pm 0.259$ & $\begin{array}{c}8.200 \pm 0.252^{*} \\
(+38.27)\end{array}$ & $5.100 \pm 0.334$ & $\begin{array}{c}6.500 \pm 0.221 * \\
(+27.45)\end{array}$ \\
\hline 28 & $5.810 \pm 0.271$ & $\begin{array}{c}8.020 \pm 0.363^{*} \\
(+38.03)\end{array}$ & $4.824 \pm 0.302$ & $\begin{array}{c}5.800 \pm 0.316 \\
\quad(+20.23)\end{array}$ \\
\hline 35 & $6.130 \pm 0.154$ & $\begin{array}{c}8.350 \pm 0.349 * \\
\quad(+36.21)\end{array}$ & $5.200 \pm 0.258$ & $\begin{array}{c}5.000 \pm 0.126 \\
(-3.84)\end{array}$ \\
\hline
\end{tabular}

* Significant difference $(P<0.05)$.

Values in parentheses indicate percentage-point change over control.

ing values: $8.200 \pm 0.252,8.020 \pm 0.363 \mathrm{ng} \cdot \mathrm{mL}^{-1}$, and $8.350 \pm 0.349 \mathrm{ng} \cdot \mathrm{mL}^{-1}$. By the end of day 7 , the plasma prolactin level was $4.500 \pm 0.221$ and increased to 10.500 \pm 0.221 by the end of day 14 . This shows a sudden percentage-point increase from 12.50 to 90.07 . But after day 14 (days 21 and 28, respectively) its level rapidly recovered reaching $6.500 \pm 0.221$ and $5.800 \pm 0.316$, showing a percentage-point increase of 27.45 and 20.23 . However, at the end of day 35 of treatment, the prolactin level decreased to $5.000 \pm 0.126$, showing a minimum decrease by 3.84 percentage points.

\section{DISCUSSION}

Fish are known to respond to environmental pollutants by way of showing alterations in the serum hormonal levels (Thomas and Khan 1997). Plasma cortisol levels are the most commonly used stress indicator in fish because of the rapid elevation that occurs in response to various stressors such as handling, confinement, poor water quality, and a wide variety of toxicants (Wendelaar Bonga 1997, Mustafa et al. 2000). Tomasso et al. (1981) reported that the release of corticosteroids into the circulation is brought about by two methods; firstly as in the case of handling, the animal perceives an external threat or disturbance and responds physiologically to meet the threat; secondly, the fish apparently is not threatened or stressed as long as the chemical remains in the environment. However, when the chemical is allowed to enter the animal, corticosteroids are released into the circulation and corticosteroid release in this case is probably a response to a physiological dysfunction brought about by the toxin.

Lorz et al. (1978) reported a significant increase in plasma cortisol level in Coho salmon Oncorhynchus kisutch exposed to cadmium, copper, and several metals, which 
may be due to the presence of metals in the ambient water. Fu et al. (1990) reported that the initial rise of cortisol concentrations following $1 \mathrm{~h}$ of $\mathrm{Cd}$ treatment (representing an alarm phase) appeared as a direct response of the fish (O. mossambicus) to a potentially harmful substance. The subsequent fall in the plasma cortisol level was considered either due to exhaustion or successful compensation. Brown and Waring (1996) in brown trout observed stimulation of proteolysis and lipolysis for gluconeogenesis leading to the elevation of plasma glucose and also appear to be related to increased cortisol levels under stressful condition. In the present study, significant increase of plasma cortisol level in Cyprinus carpio exposed to acute and sublethal copper treatment might have resulted from the recognition of the presence of a noxious substance.

It appears in the present study that the fish exposed to sublethal $\mathrm{Cu}$ treatment, went through all the three stages of General Adaptation Syndrome. The initial rise of cortisol (alarm phase) appears to be a direct response of the fish as a result of repartial of a potentiality harmful substance in water (Iwama and Nakanishi 1996). The maintenance of an elevated level during the following days apparently represents a resistance phase during which period the animal try to counteract the observed physiological changes, the subsequent fall in its (plasma cortisol) levels thereafter means the exhaustion phase supporting the biphasic character of cortisol release in fish.

Prolactin is a member of the family of adenohypophysial hormones and it has been termed a "jack of-all-trades" with more than 80 different hormonal activities ascribed to it (Nicoll and Bern 1971). Prolactin is one of the main osmoregulatory hormones in fish maintaining the plasma electrolyte levels mainly by controlling permeability of the gill epithelium. Wood (1989) reported that pollutants are known to interfere with osmotic and ionic regulations of organisms thereby indirectly altering the various physiological processes and jeopardizing the very survival of the species in such polluted environments. In the present study the observed increase in the prolactin level up to day 28 could be taken to suggest that the fish adaptively tries to overcome the changes in the hydromineral metabolism in its body under copper stress by way of the action of prolactin on gills and kidney. Further the decrease in plasma prolactin level after day 28 could be probably due to inhibitory effect of the pollutants on the adenohypophysial secretory functions.

In the present study it can be concluded that the alterations of plasma cortisol and prolactin levels can be taken as a characteristic response to stressors and these primary stress hormones can be used as a stress biomarker in fish.

\section{REFERENCES}

Anonymous 1998. Standard methods for the examination of water and wastewater, 20th edn. American Public Health Association, Washington, DC.

Barton B.A., Iwama G.K. 1991. Physiological changes in fish from stress in aquaculture with emphasis on the response and effects of corticosteroids. Annual Review of Fish Diseases 1: 3-26.
Brown J.A., Waring C.P. 1996. The physiological status of brown trout exposed to aluminium in acidic soft waters. Pp. 115-143. In: Taylor E.W. (ed.) Toxicology of Aquatic Pollution. Physiological, Cellular and Molecular Approaches. Society for Experimental Biology Seminar Series Vol. 57. Cambridge University Press, Cambridge, UK.

Bury N.R., Walker P.A., Glover C.N. 2003. Nutritive metal uptake in teleost fish. Journal of Experimental Biology 206: $11-23$.

Donaldson E.M. 1981 The pituitary-interrenal axis as an indicator of stress in fish. Pp. 11-47. In: Pickering A.D. (ed.) Stress in fish. Academic Press, London.

Engvall E. 1980. Enzyme immunoassay-ELISA and EMJT. Pp. 419-439. In: van Vunakis H., Langono J.J. (eds.) Methods in Enzymology. Vol. 70. Academic Press, New York.

Finney D.J. 1978. Statistical methods in biological assay. 3rd edn., Griffin Press, London.

Fu H., Steinebach O.M., van den Hamer C.J.A., Balm P.H.M., Lock R.A.C. 1990. Involvement of cortisol and metallathionein-like proteins in the physiological responses of tilapia (Oreochromis mossambicus) to sublethal cadmium stress. Aquatic Toxicology 16: 257-369.

Iwama G.K., Afonso, L.O.B., Todgham A., Ackerman P., Nakano K. 2003. Are hsps suitable for indicating stressed states in fish? Journal of Experimental Biology 207: 15-19.

Iwama G., Nakanishi T. 1996. The fish immune system. Organism, Pathogen, and Environment. Academic Press, San Diego.

Lorz H.W., Williams R.H., Fustish C.A. 1978. Effects of several metals on smolting of coho salmon, Oncorhynchus kisutch. (U.S. Environmental Protection Agency, Grant Report R-804283). Oregon Department of Fish and Wildlife, Corvallis, Oregon.

Mustafa A., MacWilliams C., Fernandez N., Matchett K., Conboy G.A., Burka J.F. 2000. Effects of sea lice (Lepeophtheirus salmonis Kröyer, 1837) infestation on macrophage functions in Atlantic salmon (Salmo salar L.). Fish and Shellfish Immunology 10: 47-59.

Nicoll C.S., Bern H.A. 1971. On the actions of prolactin among the vertebrates: is there a common denominator? Pp. 299-324. In: Wolstenholme G.E.W., Knight, J. (eds.) Lactogenic Hormones. Churchill Livingstone, London.

Pottinger T.G., Carrick T.R., Appleby A., Yeomans W.E. 2000. High blood cortisol levels and low cortisol receptor affinity: Is the chub, Leuciscus cephalus, a cortisol-resistant teleost? General and Comparative Endocrinology 120: 108-117.

Sloman K.A. 2003. Copper, cortisol and the common carp. Journal of Experimental Biology 206 (19): 3309.

Sloman K.A. 2004. Tough toadfish: surviving copper exposure. Journal of Experimental Biology 207 (19): vii.

Sprague J.B. 1971. Measurement of pollutant toxicity of fish III. Sublethal effects and safe concentrations. Water Research 5: 245-266.

Thomas P., Khan I.A. 1997. Mechanisms of chemical interference with reproductive endocrine function in sciaenid fishes. Pp. 29-51. In: Rolland R.M., Gilbertson M., Peterson R.E. (eds.) Chemically induced alterations in functional development and reproduction of fishes. Society of Environmental Toxicology and Chemistry Technical Publications Series, Pensacola. 
Tietz N.W. (ed.) 1986. Text Book of Clinical Chemistry. W.B. Saunders, Philadelphia.

Tomasso J.R., Davis K.B., Simco B.A. 1981. Plasma corticosteroid dynamics in channel cat fish (Ictalurus punctatus) exposed to ammonia and nitrite. Canadian Journal of Fisheries and Aquatic Sciences 38: 1106-1112.

Wendelaar Bonga S.E. 1997. The stress response in fish. Physiological Reviews 77: 591-625.

Wendelaar Bonga S.E., Flik G., Balm P.H.M. 1987. Physiological adaptation to acid stress in fish. Annales de la Société royale Zoologique de Belgique 117: 243-254.

Wendelaar Bonga S.E., Flik G., Fenwick, J.C. 1984. Prolactin and calcium metabolism in fish: Effects on plasma calcium and high-affinity $\mathrm{Ca}^{2+}-$ ATPase in gills. Pp.188-190. In: Cohn D.V., Potts jr. J.T., Fujita J. (eds.) Endocrine control of bone and calcium metabolism. Elsevier Press, New York.
Wood C.M. 1989. The physiological problems of fish in acid waters. Pp. 125-152. In: Morris R., Taylor E.W., Brown D.J.A., Brown J.A. (eds.) Acid toxicity and aquatic animals. Cambridge University Press, Cambridge, UK.

Yang C.Z., Albright L.J. 1995. Elevation of plasma cortisol and hypertrophic response of inter-renal and chromaffin tissues of rainbow trout, Oncorhynchus mykiss (Walbaum), to the harmful diatom, Chaetoceros concavicornis. Journal of Fish Diseases 18: 165-174.

Received: 11 May 2007

Accepted: 11 October 2007

Published electronically: 30 November 2007 